\title{
Komposisi dan Kelimpahan Fitoplankton di Laguna Segara Anakan, Cilacap
}

\author{
Budhy Wiyarsih*, Hadi Endrawati, Sri Sedjati \\ Departemen Ilmu Kelautan, Fakultas Perikanan dan Ilmu Kelautan, Universitas Diponegoro \\ Jl. Prof. Sudarto, SH, Tembalang, Semarang, Jawa Tengah, 50275 \\ Email: b.wiyarsih07@gmail.com
}

\begin{abstract}
Abstrak
Segara Anakan merupakan laguna yang terletak di selatan Pulau Jawa tepatnya di perbatasan antara Jawa Barat dengan Jawa Tengah. Kawasan Segara Anakan merupakan tempat bertemunya sungai besar, sehingga mengalami perubahan penurunan kualitas perairan berupa penyempitan dan pedangkalan akibat proses sedimentasi yang tinggi. Hal ini dikhawatirkan dapat mengakibatkan menurunnya kualitas perairan yang dapat mengganggu pertumbuhan fitoplankton di perairan. Fitoplankton merupakan parameter biologi yang dapat dijadikan bioindikator untuk mengevaluasi kualitas dan tingkat kesuburan suatu perairan. Kondisi tentang lingkungan perairan diperkirakan berubah sepanjang waktu, maka perlu penelitian fitoplankton, untuk mengetahui tingkat kesuburan perairannya. Tujuan dari penelitian ini adalah untuk mengetahui komposisi dan kelimpahan fitoplankton di Laguna Segara Anakan, Cilacap. Penelitian ini menggunakan metode deskriptif eksploratif dengan pengambilan data menggunakan purposive sampling method. Hasil menunjukkan ditemukan 34 genera yaitu Kelas Bacillariophyceae (21 genera), Kelas Cyanophyceae (4 genera), Dinophyceae (6 genera), Chlorophyceae (2 genera), dan Euglenophyceae (1 genus). Kelimpahan fitoplankton berkisar antara 12.945,8-38.194,1 sel/liter. Indeks Keanekaragaman termasuk kategori sedang dengan nilai berkisar 1,60 - 2,32. Indeks keseragaman termasuk kategori sedang hingga tinggi, dengan nilai berkisar 0,59-0,81. Indeks dominansi berkisar antara $0,18-0,44$. menunjukkan bahwa tidak ada genus yang mendominasi.
\end{abstract}

Kata Kunci: Komposisi, Kelimpahan, Fitoplankton, Laguna Segara Anakan

\section{Abstract \\ The composition and abundance of phytoplankton in Segara Anakan Lagoon, Cilacap}

Segara Anakan is a lagoon located in the south of Java Island precisely on the border between West Java and Central Java. Segara Anakan area is the place where the big river meets. Water quality decrease because of narrowing the lagoon due to the high sedimentation process. This may affect the presence of phytoplankton in the water. The quality and the fertility level of aquatic can be evaluated through the phytoplankton existence since phytoplankton is used as a biological indicator for the marine environment. The condition of the aquatic environment is expected to change over time, so it is necessary to study phytoplankton. The purpose of this research is to know about the composition and abundance of phytoplankton in Segara Anakan Lagoon, Cilacap. This research used the descriptive explorative method by data sampling using purposive sampling method. The study showed 34 genera of Bacillariophyceae (21 genera), Cyanophyceae (4 genera), Dinophyceae (6 genera), Chlorophyceae (2 genera), and Euglenophyceae (1 genus). The abundance of phytoplankton ranging from 12.945,8-38.194,1 cells/liter. The Diversity Index is a medium category with values ranging from 1.60 to 2.32. The evenness index is moderate to high, with values ranging from 0.59 to 0.81 . The Dominant index ranges from 0.18 to 0.44 . The value indicates the category of no dominating genus.

Keywords: Composition, Abundance, Phytoplankton, Segara Anakan Lagoon

\section{PENDAHULUAN}

Plankton merupakan organisme akuatik yang berukuran mikroskopik, mempunyai kekuatan berenang yang lemah sehingga pergerakannya mengikuti gerakan arus air. Plankton terdiri dari dua jenis yaitu fitoplankton dan zooplankton. Fitoplankton bersifat autotrof dan menjadi produsen utama yang menyediakan energi bagi organisme akuatik lainnya, sedangkan zooplankton bersifat heterotrof yang memerlukan peranan dari fitoplankton sebagai 
produsen untuk memenuhi kebutuhan energinya (Aryawati, 2007).

Fitoplankton terutama diatom merupakan produser primer terbanyak di perairan, mereka terdapat disemua bagian lautan tetapi melimpah dipermukaan massa air yang terdapat banyak nutrient sehingga akan mempengaruhi kesuburan suatu perairan Romimohtarto dan Juwana (2007). Keberadaan fitoplankton sebagai produsen primer di perairan sangat tergantung pada unsur hara dan kualitas lingkungan pada daerah tersebut. Fitoplankton juga bergantung pada kondisi beberapa faktor, seperti kedalaman, kecerahan, suhu, arus, salinitas, pH, oksigen terlarut (DO), dan nutrien. Adapun faktor biotik yang mempengaruhi adalah distribusi dan predasi (Sundari, 2016).

Segara Anakan merupakan laguna yang terletak di selatan Pulau Jawa tepatnya di perbatasan antara Provinsi Jawa Barat dengan Jawa Tengah. Segara Anakan terdapat muara sungai besar Kawasan Segara Anakan merupakan tempat bertemunya sungai besar, yaitu Sungai Citanduy, Sungai Cibereum dan Sungai Cikonde di bagian barat serta Sungai Sapuregel, Sungai Donan, dan Sungai Yasa di bagian timur. Daerah ini selalu mengalami perubahan penurunan kualitas perairan berupa penyempitan dan pedangkalan akibat proses sedimentasi yang tinggi (Pribadi et al., 2009).

Daerah Plawangan merupakan daerah yang langsung berhubungan dengan Samudera Hindia. Daerah Klaces adalah daerah pengerukan (dredging) dan jalur utama lalu lintas penduduk menggunakan kapal. Daerah Donan merupakan daerah muara sungai dan merupakan area industri minyak Pertamina, Semen Nusantara, pertambangan, dermaga Perhutani, dermaga pasir besi, dermaga Pertamina, termasuk kawasan penduduk (Djohan, 2010).

Kondisi perairan yang komplek dapat mempengaruhi keadaan hidrooseanografi. Odum (1993) menjelaskan bahwa akibat perubahan kondisi kualitas air akan menyebabkan terjadinya perubahan ekosistem dan komposisi komunitas organisme. Salah satu organisme yang merasakan langsung pengaruh tersebut adalah fitoplankton.

Kondisi Laguna Segara Anakan diperkirakan berubah sepanjang waktu dan akan berdampak pada fitoplankton maupun komposisinya, maka perlu diadakan penelitian tentang kelimpahan dan struktur komunitas fitoplankton di Segara Anakan Cilacap.

\section{MATERI DAN METODE}

Metode pengambilan sampel menggunakan plankton net dengan mesh size $45 \mu \mathrm{m}$ (plankton net). Pengambilan sampel dilakukan secara horizontal yaitu pengambilan sampel dengan cara ditarik horisontal (Hasrun et al., 2013). Pengukuran parameter lingkungan yang meliputi salinitas, nutrien, suhu, kecerahan, $\mathrm{pH}, \mathrm{DO}$ dilakukan pada saat pengambilan sampel secara in situ di lokasi penelitian (Gambar 1). Sampel air juga diambil sebanyak $600 \mathrm{ml}$ untuk parameter fosfat dan nitrat dengan botol gelap.

\section{Analisi data}

Kelimpahan fitoplankton dinyatakan dalam individu per liter. Kelimpahan fitoplankton dikalkulasi dengan menggunakan rumus (Arinardi et al., 1997). Indeks Keanekaragaman (H') menurut Shannon-Weiner (Meiriyani et al., 2011) Kisaran Indeks Keanekaragaman adalah sebagai berikut : $0-1=$ kategori rendah; 2-3 = kategori sedang; >3 = kategori tinggi

Keseragaman adalah penyebaran individu antar spesies atau genus yang berbeda dan diperoleh dari hubungan antara keanekaragaman (H') dengan keanekaragaman maksimalnya (Odum, 1993). Indeks keseragaman dapat dihitung dengan rumus dari Basmi (1997).

Menurut Odum (1993), besarnya indeks keseragaman berkisar 0-1 sebagai berikut: e>0,6= Keseragaman jenis tinggi; $0,6 \geq \mathrm{e} \geq 0,4=$ Keseragaman jenis sedang; e $<0,4=$ Keseragaman jenis rendah

Indeks Dominansi digunakan untuk mengetahui sejauh mana suatu spesies atau genus mendominasi kelompok lain. Metode perhitungan yang digunakan adalah rumus indeks dominansi Simpson (Odum, 1993). Kriteria indeks dominansi menurut Odum (1993) adalah sebagai berikut: $0<\mathrm{C} \leq 0,5=$ Tidak ada genus yang mendominasi; $0,5<\mathrm{C}<1=$ Terdapat genus yang mendominasi.

\section{HASIL DAN PEMBAHASAN}

Berdasarkan hasil penelitian yang dilakukan pada pada 3 area yang terbagi dalam 11 titik di Segara Anakan, Cilacap diketahui bahwa komposisi fitoplankton yang ditemukan di lokasi terdiri dari 5 kelas fitoplankton berjumlah 34 genera yang terdiri dari kelas Bacillariophyceae (21 genera), Cyanophyceae (4 genera), Dinophyceae (6 genera), Chlorophyceae (2 genera), dan Euglenophyceae (1 genus). 


\section{Faktor-faktor kualitas Perairan}

Hasil pengukuran rata-rata kualitas air didapatkan data sebagai berikut: area Plawangan bulan Desember memiliki suhu $27-29{ }^{\circ} \mathrm{C}$, salinitas 7-21 ppt, pH 6-7, kecerahan 40-230 cm, dan DO 4,0-4,5 mg/liter, sedangkan bulan Januari memiliki suhu $27-29{ }^{\circ} \mathrm{C}$, salinitas10-24 ppt, pH 78, kecerahan 10-60 cm, dan DO 4,0-4,5 mg/liter. Area Klaces bulan Desember memiliki suhu 27-29 ${ }^{\circ} \mathrm{C}$, salinitas 9-22 ppt, pH 6-8, kecerahan 50-126 $\mathrm{cm}$, dan DO 4,0 mg/liter, sedangkan bulan Januari memiliki memiliki suhu $27-29^{\circ} \mathrm{C}$, salinitas $10-23$ ppt, pH 7-8, kecerahan 40-100 cm, dan DO 4,5 mg/liter. Area Donan bulan Desember memiliki suhu 30-31 ${ }^{\circ} \mathrm{C}$, salinitas 22-27 ppt, pH 7-8, kecerahan 120-270 cm, dan DO 4,0-4,5 mg/liter, sedangkan bulan Januari memiliki suhu $29-31{ }^{\circ} \mathrm{C}$, salinitas 18-24 ppt, pH 7-8, kecerahan 60-285 cm, dan DO 4,0-4,5 mg/liter.

Kandungan fosfat area Plawangan pada bulan Desember adalah $0.0020 \mathrm{mg} / \mathrm{liter}$, dan di bulan Januari adalah $0,0288 \mathrm{mg} / \mathrm{liter}$. Kandungan nirat bulan Desember $0,2727 \mathrm{mg} / \mathrm{liter}$, bulan Januari $0,0200 \mathrm{mg} / \mathrm{liter}$. Kandungan fosfat area Klaces pada bulan Desember adalah 0,0020 $\mathrm{mg} / \mathrm{liter}$, dan di bulan Januari adalah 0,0554 $\mathrm{mg} / \mathrm{liter}$. Kandungan nirat bulan Desember 0,1991 $\mathrm{mg} / \mathrm{liter}$, bulan Januari $0,0200 \mathrm{mg} / \mathrm{liter}$. Kandungan fosfat area Donan pada bulan Desember adalah 0,0020 mg/liter, dan bulan
Januari adalah 0,0484 $\mathrm{mg} /$ liter. Kandungan nitrat bulan Desember 0,2294 mg/liter, bulan Januari 0,0200 mg/liter (Tabel 1).

\section{Komposisi fitoplankton}

Hasil penelitian menggambarkan bahwa jumlah genus fitoplankton yang ditemukan lebih sedikit jika dibandingkan dengan hasil penelitian yang dilakukan Aris (2006) menemukan 59 genera fitoplankton dari kelas yang sama. Jumlah fitoplankton yang sedikit diduga karena nilai curah hujan yang rendah (Gambar 2, 3 dan 4). Curah hujan yang tinggi menyebabkan melimpahnya nutrien seperti seperti nitrat dan fosfat di perairan (Meirinawati dan Muchtar 2017). Hal ini disebabkan karena teraduknya dasar perairan sehingga terangkatnya nutrient seperti nitrat dan fosfat kepermukaan. sehingga menjadi lebih subur.

Berdasarkan hasil yang ditemukan, secara umum Genus Coscinodiscus (kelas Bacillariophyceae) merupakan genus yang paling sering ditemukan diseluruh lokasi. Genus tersebut banyak ditemukan di perairan karena daya adaptasi salinitas yang lebih baik dari pada kelas yang lain. Menurut Madinawati (2012), tingginya kelimpahan Bacillariophyceae disebabkan karena organisme ini dominan ditemukan di perairan laguna, karena daerah laguna banyak aliran sungai yang membawa nutrien seperti nitrat dan fosfat.

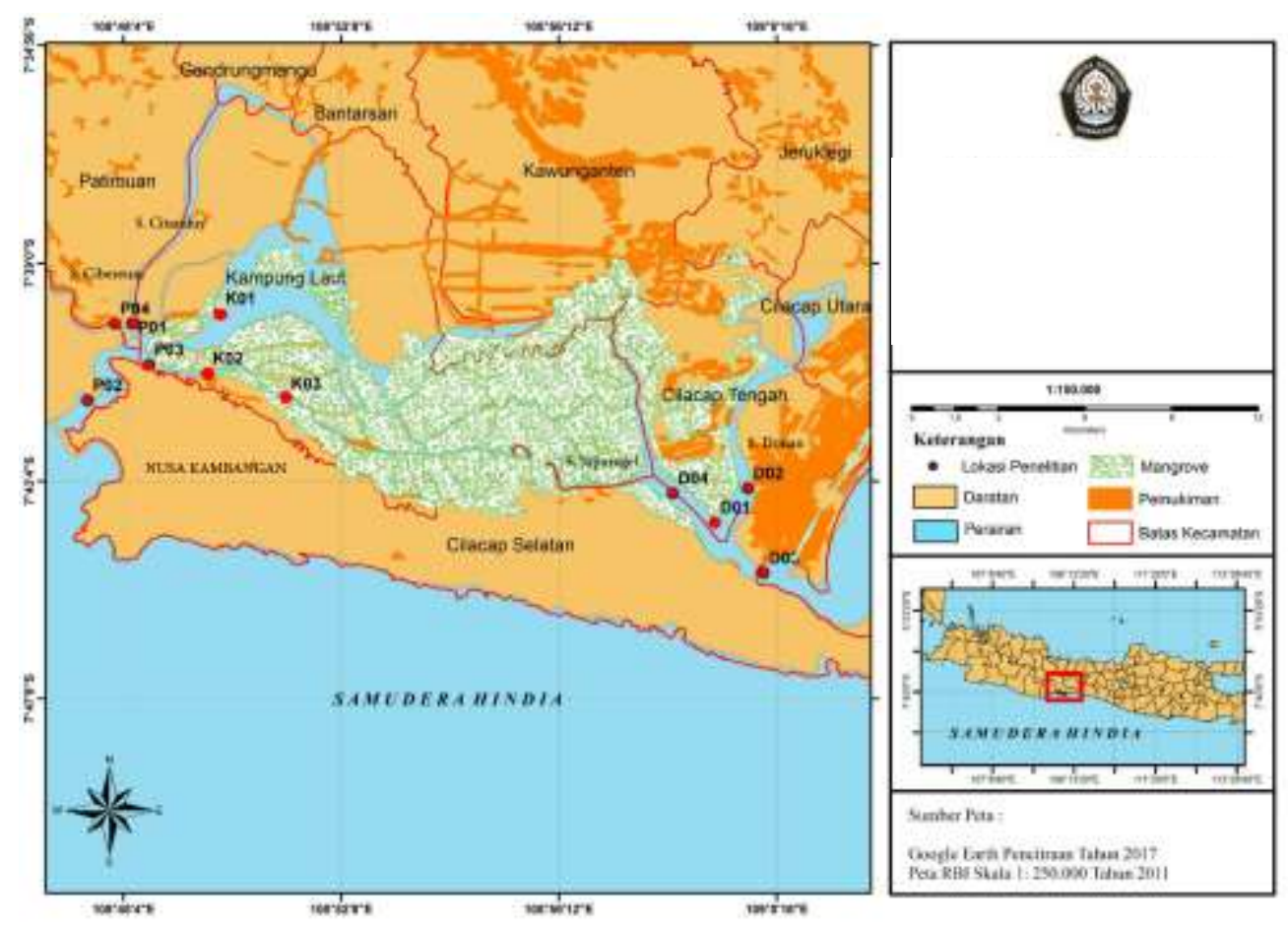

Gambar 1. Peta Lokasi Penelitian Komposisi dan Kelimpahan Fitoplankton di Segara Anakan, Cilacap 
Komposisi fitoplankton di area Plawangan pada bulan Desember berjumlah 27 genera, sedangkan bulan Januari berjumlah 26 genera. Bedasarkan hasil yang ditemukan genus yang paling banyak dijumpai adalah Coscinodiscus dan Nitzschia. Hal ini karena periran tersebut mempunyai kandungan nitrat $0,2727 \mathrm{mg} / 1$ dan fosfat $0,0020 \mathrm{mg} / \mathrm{l}$, yang cukup baik genus Coscinodiscus dan Nitzschia juga sangat membutuhkan nutrient seperti nitrat dan fosfat untuk menunjang pertumbuhannya selain itu mampu bertahan pada perairan yang memiliki intensitas cahaya yang sedikit, dan salinitas yang rendah,. pada area tersebut terdapat muara sungai besar yaitu Sungai Citanduy dan Sungai Cibereum, serta curah hujan yang tinggi yang menjadikan perairan mempunyai salinitas rendah namun kandungan nutrien seperti nitrat dan fosfat cukup tinggi.

Komposisi fitoplankton di area Klaces bulan Desember sebesar 22 genera, sedangkan bulan Januari 25 genera. Genus yang paling banyak ditemukan adalah genus Coscinodiscus dan Oscillatoria. Genus Oscillatoria banyak ditemukan karena area ini mempunyai nilai parameter lingkungan yang cocok serta nilai fosfat yang tinggi. Genus Oscillatoria (kelas Cyanophyceae) mampu berkembang baik pada kadar fosfat kisaran fosfat optimum bagi petumbuhan fitoplankton adalah $0,09-1,80 \mathrm{mg} / \mathrm{l}$ dan pada saat konsentrasi fosfat tinggi yaitu di atas $0,10 \mathrm{mg} / \mathrm{l}$ maka akan didominasi oleh Cyanopyceae (Sianipar et al., 2015). Menurut Djohan (2010) genus Oscillatoria adalah alga pengikat nitrogen, dan hidup dengan baik di area Klaces. Bila dibandingkan dengan kondisi penelitian, dapat disimpulkan bahwa konsentrasi fosfat di Plawangan, Klaces dan Donan lebih tinggi pada bulan Januari dibandingkan bulan Desember.

Komposisi fitoplankton di area Donan pada bulan Desember sebesar 22 genera, sedangkan bulan Januari 34 genera. Komposisi fitoplankton di area ini merupakan yang tertinggi. Genus yang paling banyak ditemukan adalah genus Coscinoddiscus dan Pleurosigma. Genus dari kelas Bacillariopyceae ini mampu bertahan pada kondisi lingkungan yang tercemar. Area ini terdapat banyak pabrik dan limbah pemukiman penduduk. Banyaknya fitoplankton didukung adanya nutrien yang berasal dari limbah rumah tangga, muara Sungai Donan dan Sungai Yasa.

\section{Kelimpahan fitoplankton}

Kelimpahan fitoplankton di area Plawangan bulan Desember sebesar 22.343,2 sel/liter, sedangkan Januari sebesar 14.115,6 sel/liter. Tingginya kelimpahan di area ini diduga karena curah hujan bulan Januari 2017 yang lebih sedikit

Tabel 1. Hasil Pengukuran Parameter Lingkungan di Segara Anakan, Kabupaten Cilacap

\begin{tabular}{|c|c|c|c|c|}
\hline Parameter & Area & Desember $\left.^{*}\right)$ & Januari $^{*}$ & Baku Mutu $^{* *}$ \\
\hline \multirow[t]{3}{*}{ Suhu $\left({ }^{\circ} \mathrm{C}\right)$} & Plawangan & $27-29$ & $27-29$ & $28-30^{\circ} \mathrm{C}$ \\
\hline & Klaces & $27-29$ & $27-29$ & \\
\hline & Donan & $30-31$ & $29-31$ & \\
\hline \multirow[t]{3}{*}{ Salinitas (ppt) } & Plawangan & $7-21$ & $10-24$ & 33-34 \\
\hline & Klaces & $9-22$ & $10-23$ & \\
\hline & Donan & $22-27$ & $18-24$ & \\
\hline \multirow{3}{*}{ Kecerahan (cm) } & Plawangan & $40-230$ & $10-60$ & $>3$ \\
\hline & Klaces & $50-126$ & $40-110$ & \\
\hline & Donan & $120-270$ & $60-285$ & \\
\hline \multirow[t]{3}{*}{ DO (mg/liter) } & Plawangan & $4,0-4,5$ & $4,0-4,5$ & $>5$ \\
\hline & Klaces & 4,0 & 4,5 & \\
\hline & Donan & $4,0-4,5$ & $4,0-4,5$ & \\
\hline \multirow[t]{3}{*}{$\mathrm{pH}$} & Plawangan & $6-7$ & $7-8$ & $7-8.5$ \\
\hline & Klaces & $6-8$ & $7-8$ & \\
\hline & Donan & $7-8$ & $7-8$ & \\
\hline \multirow[t]{3}{*}{ Nitrat (mg/liter) } & Plawangan & 0,2727 & $\leq 0,0300$ & 0,008 \\
\hline & Klaces & 0,1991 & $\leq 0,0200$ & \\
\hline & Donan & 0,2294 & $\leq 0,0200$ & \\
\hline \multirow[t]{3}{*}{ Fosfat (mg/liter) } & Plawangan & $\leq 0,0020$ & 0,0288 & 0,015 \\
\hline & Klaces & $\leq 0,0020$ & 0,0554 & \\
\hline & Donan & $\leq 0,0020$ & 0,0484 & \\
\hline
\end{tabular}

Sumber :

*) Hasil penelitian; **) Kep.51/MENKLH/2004 
dari bulan Desember 2016. Data BMKG menunjukkan curah hujan sebesar $480 \mathrm{~mm}$ pada bulan Desember 2016 dan 400 mm bulan Januari 2017. Curah hujan yang tinggi menyebabkan laguna lebih banyak mendapatkan pasokan air tawar yang berasal dari sungai maupun air hujan. Akibatnya fitoplankton air tawar juga ditemukan di laguna, yaitu genus Euglena dari kelas Euglenophyceae. Juga masuknya aliran sungai akan membawa nutrient seperti nitrat dan fosfat yang cukup baik.

Kelimpahan fitoplankton di area Klaces bulan Desember sebesar 12.946,8 sel/liter, sedangkan bulan Januari sebesar 19.652,6 sel/liter (Gambar 5). Selain faktor curah hujan yang dapat mempengaruhi pertumbuhan fitoplankton, juga jumlah nutrient seperti nitrat dan fosfat dimana kandungan nitrat pada bulan Januari adalah $0,0200 \mathrm{mg} / \mathrm{l}$ dan fosfat $0,0554 \mathrm{mg} / \mathrm{l}$, yang kurang mendukung untuk kehidupan dan laju pertumbuhan fitoplankton, aktivitas pengerukan di area ini juga dapat mempengaruhi penetrasi cahaya matahari dalam perairan. Hal ini didukung pernyataan Romimohtarto dan Juwana (2007), bahwa laju pertumbuhan maksimum fitoplankton akan mengalami penurunan bila perairan berada pada kondisi ketersediaan cahaya matahari yang rendah.

Kelimpahan fitoplankton pada area Donan bulan Desember sebesar 29.888,4 sel/liter, sedangkan bulan Januari sebesar 38.194,1 sel/liter. Kelimpahan yang tinggi di area ini didukung adanya muara sungai. Keberadaan muara sungai sangat berpengaruh pada kelimpahan fitoplankton karena daerah muara sungai mempunyai kadar nutrien tinggi terutama nitrat $0,2294 \mathrm{mg} / \mathrm{l}$ dan fosfat $0,0020 \mathrm{mg} / \mathrm{l}$ yang sangat dibutuhkan bagi perkembangbiakan dan pertumbuhan fitoplankton. Fosfat dan nitrat merupakan kebutuhan utama fitoplankton, sehingga jika keberadaannya di perairan sedikit maka fitoplankton juga akan mengalami penurunan. Hal ini sesuai dengan pernyataan Sihombing et al., (2013), bahwa keberadaan fitoplankton banyak ditemukan di permukaan perairan yang dekat dengan darat (estuari) karena daratan banyak menyediakan nutrien seperti nitra dan fosfat di perairan.

Indeks Keanekaragaman, Indeks Keseragaman, dan Indeks Dominansi

Menurut Odum (1993) Indeks Keanekaragaman menunjukkan jumlah spesies yang mampu beradaptasi dengan lingkungan tempat hidup organisme tersebut. Menurut
Nybakken (1992), bahwa indeks keanekaragaman suatu komunitas mempunyai nilai tinggi menunjukkan bahwa ekosistem di daerah tersebut memiliki lingkungan yang seimbang, apabila nilai keanekaragaman rendah menunjukkan ekosistem perairan tersebut dalam keadaan tidak stabil dan kurang mendukung kehidupan biota.

Nilai keanekaragaman pada bulan Desember di area Plawangan menunjukkan nilai tertinggi sebesar 2,32 (Gambar 6). Nilai tersebut termasuk kategori sedang. Nilai indeks keanekaraman pada bulan Januari di area Donan menunjukkan nilai terendah dengan nilai sebesar 1,60. Nilai tersebut termasuk kategori rendah. Hal ini menunjukkan bahwa di area tersebut mempunyai kestabilan komunitas yang rendah. Menurut Odum (1993), nilai indeks keanekaragaman yang rendah menunjukkan kemampuan fitoplankton untuk memanfaatkan serta toleransi terhadap faktor lingkungan yang kurang, sehingga hanya terdapat genus tertentu yang melimpah. Sebaliknya, nilai keanekaragaman tinggi dapat disebabkan kemampuan spesies beradaptasi dengan lingkungan sehingga produktivitas tinggi.

Indeks keseragaman tertinggi ditemukan di area Plawangan sebesar 0,81, yang menunjukkan kategori tinggi (Gambar 7). Nilai indeks keseragaman yang terendah ditemukan di area Donan dengan nilai 0,56 . Nilai ini termasuk kategori sedang. Menurut Odum (1993) menyatakan bahwa nilai indeks keseragaman tinggi menunjukkan penyebaran individu merata, dan setiap genus memiliki peluang yang sama untuk memanfaatkan nutrien seperti nitrat dan fosfat yang tersedia walaupun jumlahnya terbatas. Jika nilai indeks keanekaragaman sedang, maka nilai keseragaman sedang.

Adanya perbedaan nilai indeks keragaman dan keseragaman yang bervariasi pada perairan menurut Pratiwi dan Widyastuti (2013) disebabkan oleh faktor fisika air serta ketersediaan nutrisi dan pemanfaatan nutrisi yang berbeda dari tiap individu. Faktor-faktor yang mempengaruhi nilai indeks keanekaragaman dan keseragaman dapat berasal dari faktor lingkungan yaitu ketersediaan nutrisi seperti fospat dan nitrat, serta kemampuan dari masing-masing jenis fitoplankton untuk beradaptasi dengan lingkungan yang ada.

Nilai indeks dominansi yang didapat dari hasil penelitian menunjukkan nilai yang bervariasi pada setiap lokasi. Nilai indeks dominansi bulan Desember 2016 berkisar antara 0,18-0,39, 


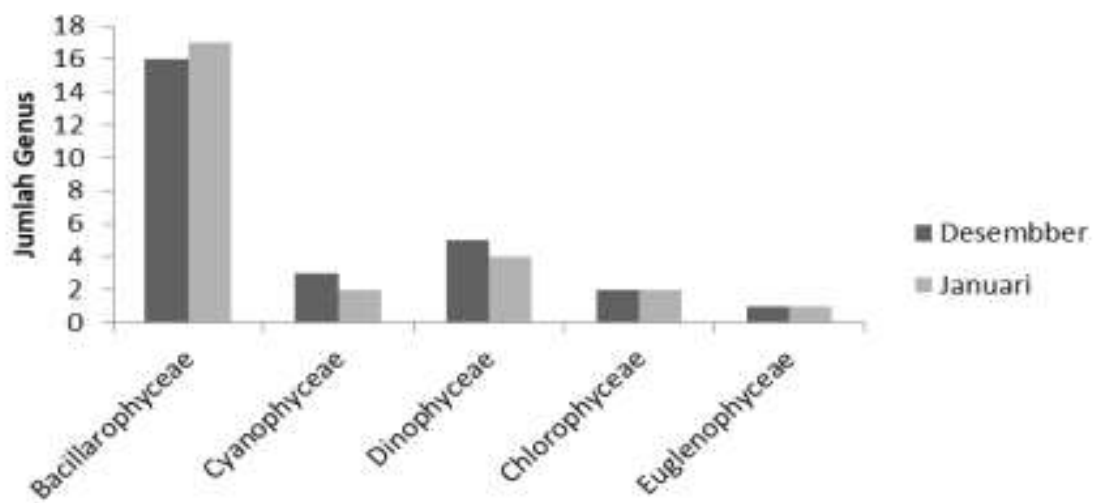

Gambar 2. Jumlah genus fitoplankton di area Plawangan

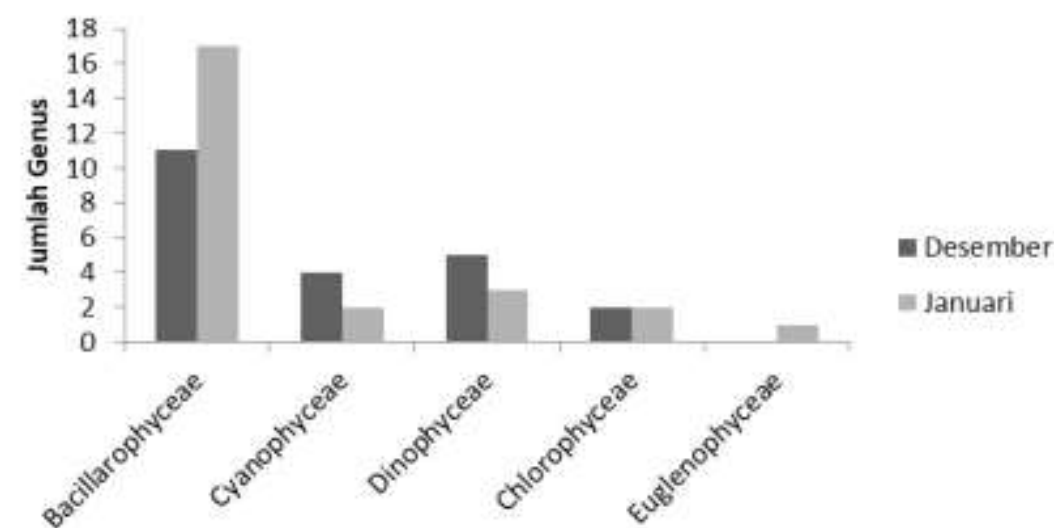

Gambar 3. Jumlah genus fitoplankton di area Klaces

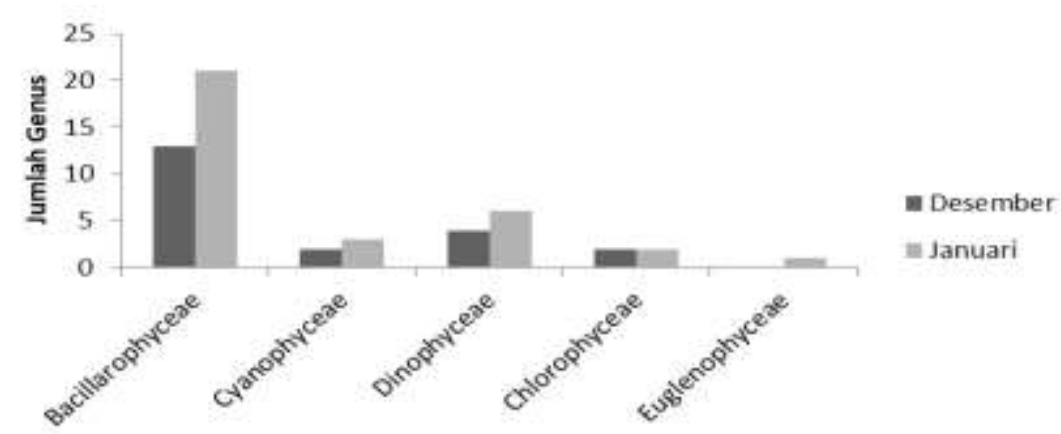

Gambar 4. Jumlah Genus Fitoplankton di area Donan

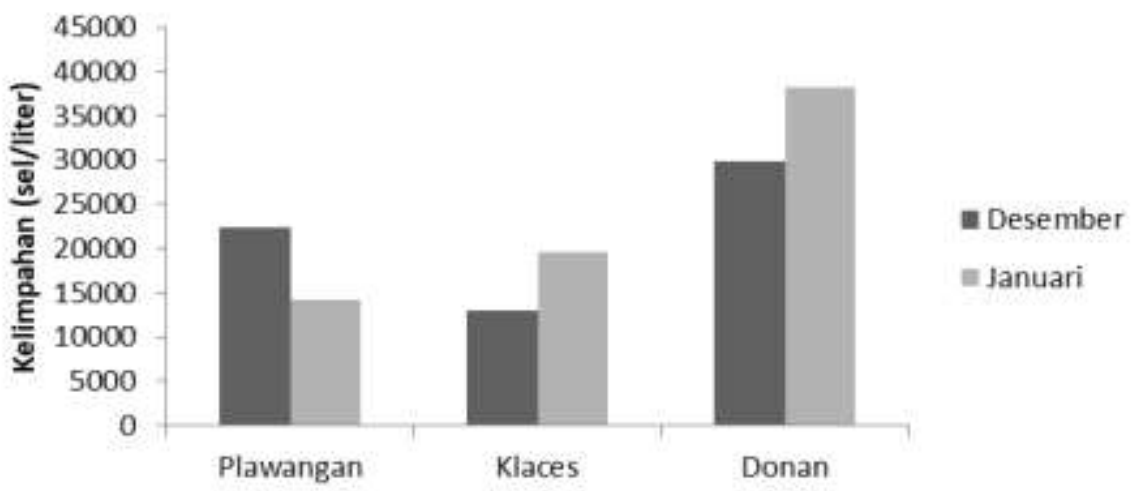

Gambar 5. Kelimpahan Rata-Rata Fitoplankton di Segara Anakan, Cilacap 


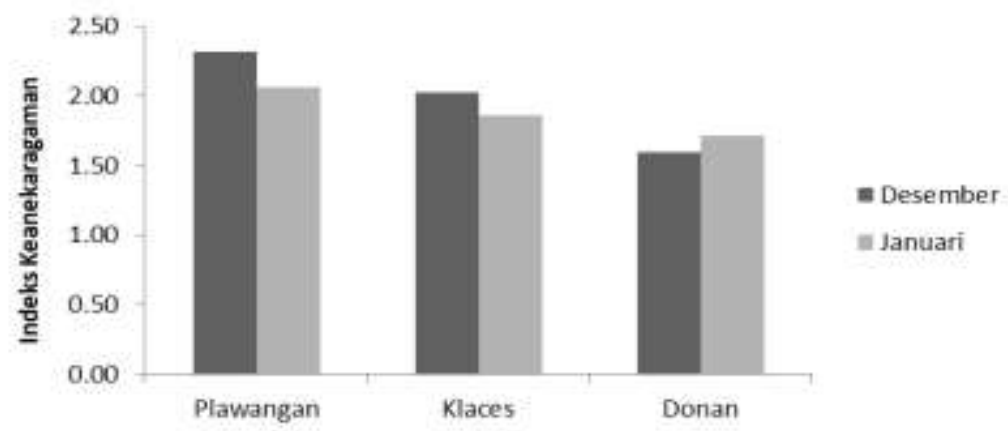

Gambar 6. Indeks Keanekaragaman Fitoplankton dari Laguna Segara Anakan, Cilacap

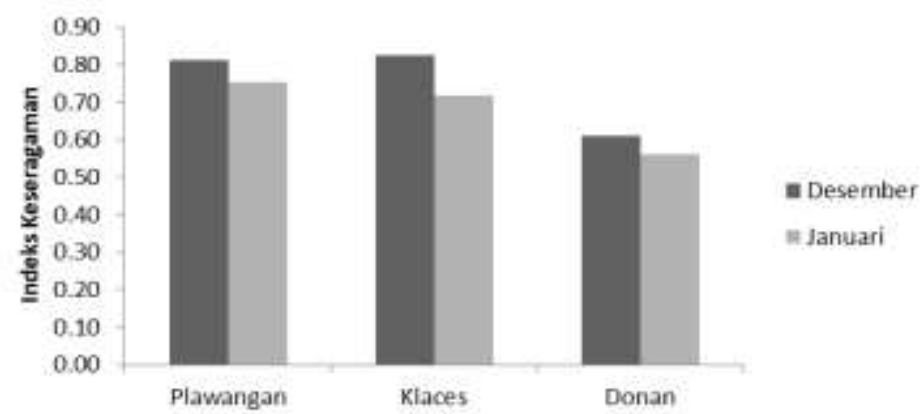

Gambar 7. Indeks Keseragaman Fitoplankton dari Laguna Segara Anakan, Cilacap

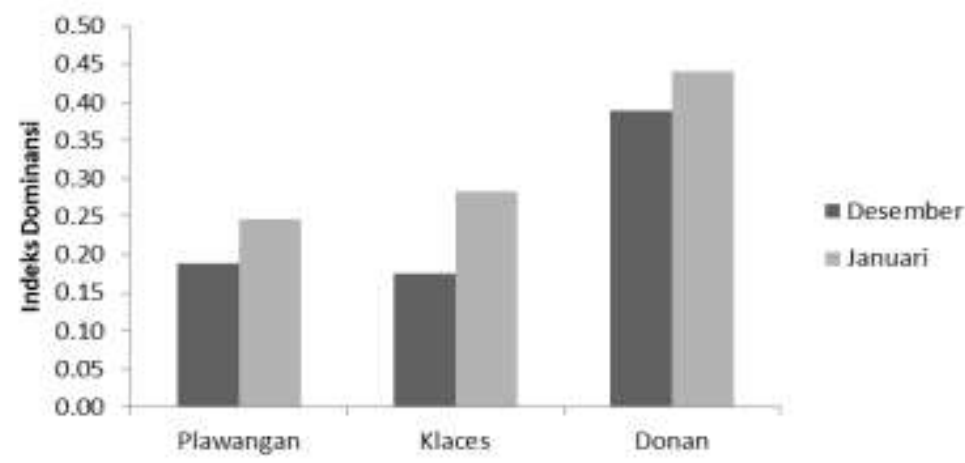

Gambar 8. Indeks Dominansi Fitoplankton dari Laguna Segara Anakan, Cilacap

sedangkan bulan Januari 2017 berkisar 0,25-0,44 (Gambar 8). Nilai indeks tertinggi di area Donan sebesar 0,44 . Nilai yang terendah terdapat di

Klaces dengan nilai 0,18 . Nilai tersebut termasuk kategori rendah dan menunjukkan tidak ada genus yang mendominasi. Hal tersebut sesuai dengan pernyataan Odum (1993), bahwa indeks dominansi yang mendekati 0 menunjukkan tidak adanya dominansi genus tertentu, sebaliknya apabila nilai indeks mendekati 1 maka ada genus yang mendominasi. Hal ini dapat disimpulkan bahwa di Laguna Segara Anakan tidak terjadi dominansi.

\section{KESIMPULAN}

Komposisi fitoplankton yang ditemukan di lokasi terdiri dari 5 kelas fitoplankton berjumlah
34 genera yang terdiri dari kelas Bacillariophyceae (21 genera), Cyanophyceae (4 genera), Dinophyceae (6 genera), Chlorophyceae (2 genera), dan Euglenophyceae (1 genus). Fitoplankton jenis tertentu memiliki kemampuan untuk bertahan dari kondisi yang tidak stabil untuk tumbuh.

\section{DAFTAR PUSTAKA}

Arinardi, O.H., A.B. Sutomo., S.A. Yusuf., Trimaningsih., Asnaryanti \& S.H. Riyono. 1997. Kisaran Kelimpahan dan Komposisi Plankton Predominan di Kawasan Timur Indonesia. LIPI, Jakarta.

Aris, K. 2006. Struktur Komunitas fitoplankton di Segara Anakan bulsn September-Desember 2006. [Skripsi]. Fakultas Perikana dan Ilmu 
Kelautan. Universitas Diponegoro, Semarang.

Aryawati, R. 2007. Kelimpahan dan Sebaran Fitoplankton di Perairan Berau Kalimantan Timur. Institut Pertanian Bogor, Bogor.

Basmi, J. 1997. Terminologi dan Klasifikasi Zooplankton Laut. Institut Pertanian Bogor, Bogor.

Djohan, T.S., 2010. Dinamika Komunitas Plankton di Perairan Ekosistem Hutan Bakau Segara Anakan yang sedang Berubah. Jurnal Manusia dan Lingkungan. 17(3):135-149.

Hasrun, L., Ma'ruf, K., \& Salwiyah. 2013. Studi Biodiversitas Diatom Bentik pada Areal Mangrove di Perairan Kecamatan Kolono Kabupaten Konawe Selatan. Jurnal Mina Laut Indonesia, 2(06):35-47.

Madinawati, M., 2012. Kelimpahan dan Keanekaragaman Plankton Di Perairan Laguna Desa Tolongano Kecamatan Banawa Selatan. Media Litbang Sulteng, 3(2):119123.

Meirinawati, H. \& Muchtar, M., 2017. Fluktuasi Nitrat, Fosfat dan Silikat di Perairan Pulau Bintan. Jurnal Segara, 13(3):141-148

Nybakken, J.W. 1992. Biologi Laut Suatu Pendekatan Ekologi. Penerbit PT. Gramedia, Jakarta.

Odum, E.P. 1993. Dasar dasar Ekologi. Edisi ke III . Diterjemahkan oleh Tjahjono, S. Gajah Mada University Press. Yogyakarta.
Pratiwi, R. \& Widyastuti, E., 2013. Pola sebaran dan zonasi krustasea di hutan bakau perairan Teluk Lampung. Zoo Indonesia, 22(1):11-21

Pribadi, R., Hartati, R., \& Suryono, C.A.. 2009. Komposisi Jenis dan Distribusi Gastropoda di Kawasan Hutan Mangrove Segara Anakan Cilacap. Jurnal Ilmu Kelautan 14(2):103-111

Romimohtarto, K, \& Juwana, S. 2007. Biologi laut. Penerbit Djambatan, Jakarta.

Sianipar, E.D., Siagian, M. \& Simarmata, A.H., 2015. Nitrate Concentration from the Water around the Floating Cage fish culture area and from the area with no cage, in the DAM Site PLTA Koto Panjang. Jurnal Online Mahasiswa Bidang Perikanan dan Ilmu Kelautan, 2(1):1-11.

Sihombing, R.F., Aryawati, R. \& Hartoni. 2013. Kandungan Klorofil-a Fitoplankton di Sekitar Perairan Desa Sungsang Kabupaten Banyuasin Provinsi Sumatera Selatan. Jurnal Maspari, 5(1): 34-39.

Sundari, P.P.K. 2016. Identifikasi Fitoplankton Di Perairan Sungai Pepe Sebagaisalah Satu Anak Sungai Bengawan Solo Di Jawa Tengah. Prosiding Seminar Nasional Pendidikan dan Saintek 2016. Hal 10061011. 